\title{
Role of crosslinked protein in lung injury following total body irradiation and bone marrow transplantation
}

\author{
Soo Young Lee $e^{1,3}$, Young Jin Kim² \\ and Yeun Jung Kim ${ }^{1}$ \\ 'Department of Natural Sciences \\ ${ }^{2}$ Department of Plasic Surgery \\ Colege of Medicine, The Catholic University of Korea \\ Seoul 137-701, Korea \\ ${ }^{3}$ Corresponding author: Tel, 82-2-590-1263; \\ Fax, 82-2-592-7068; E-mal, Isyng@catholic.ac.kr
}

Accepted 8 December 2003

Abbreviations: BAL, bronchoalveolar larvage; $\mathrm{BMT}$, bone marrow transplantation; DTT, dithiothreito; IP, interstitial pneumonitis; PBS, phosphate buffered saline; SDS, sodium dodecyl sulfate; SGM, standard gas mixture; TBI, btal body irradiafion; TBS, tris-buffered saline; TGase, transglutaminase; XIII, blood coagulation factor XIII; VCO, carbon monoxide uptake

\begin{abstract}
The aberrant protein crosslinks form ation during lung injury as results total body irradiation (TBI) and bone marrow transplantation (BMT) therapy has been examined as apossible contributory factor in organ or tissue pathogenesis. Female $\mathrm{C} 3 \mathrm{HeB}$ I FeJ mice were used for an experimental animal. Carbon monoxide uptake $\left(\mathrm{V}_{\mathrm{co}}\right)$ was measured at 1, 2, 3, 4 and 5 months after TBI at respective doses of $12,14,16$ and 18 Gy $16 \mathrm{~h}$ prior to syngeneic BMT. Also as a measure of aberrant prote in crosslinking in the inured tissues, trans glutaminase (TGase)-activities and crosslinked protein were examined along with thrombin, a protease known to activate TGases. Reductions of $V_{c o}$ were detected following TBI and BMT. Activities of thrombin and TGase 1, and crosslinked protein in bronchoalveolar lavage (BAL) fluid of the mice 1 wk after TBI at 12 Gy and BMT were identified and found to be elevated in the treated animals. These findings suggest that elevated levels of cross. linked proteins and TGase I in the bronchoalveolar larvage during the lung injury could have enhanced the organ pathogenesis following TBI and BMT.
\end{abstract}

Keywords: carbon monoxide uptake; crosslinked pro- tein; thrombin; total body irradiation and bone marrow transplantation; transglutaminases

\section{Introduction}

Bone marrow transplant (BMT) has become an effective treatment choice for various hemopoietic disorders such as acute leukemias, immune deficiency disorders, congenital metabolic disorders and severe aplastic anemia (Kersey et al., 1982; McGlave et al. 1982; O'Leary et al., 1983; Rappaport et al., 1983; Molls et al., 1986; Vriesendorp et al., 1994). The effectiveness of BMT is crossly associated with patient status of prior elimination of existing malignant plasma cells by excessive irradiation treatment. During irradiation therapy, some organs are more sensitive than other tissues where lung is one of the organs known to show a dose-limiting tolerance for total body irradiation (TBI). The frequent failure of BMT therapy may be due to an incidence of interstitial pneumonitis (IP). The reported incidence of IP in allogeneic BMT ranged from $29 \%$ to $55 \%$ with a fatality rate of up to $69 \%$ (Penny and Rubin, 1997). It is estimated that about $25 \%$ of patients who undergo allogeneic BMT die from conditions related to IP. The etiology of IP is not clearly known. However, the effect of radiation on lung tissue is considered to be one of the major contributing factors. Recently, many candidates for inducing lung radiation injury have been reported-TGF- $\beta$ (Anscher et al., 1995), IL-4 (Būttner et al., 1997), IL-6 (Chen et al., 2001) and thrombin (Huang et al., 2001). Aberrant protein oxidation may have induced irreversible aggregation and protein cross-linking in the inflamed and injured tissue due to excess irradiation. Such radiation caused protein crosslinking may have precipitated consequential tissue fibriosis. Protein crosslinking is catalyzed by transglutaminases (TGases) that are known to catalyze $\mathrm{N}^{\ell}$-( $($-glutamyl) lysine crosslinks. Multiple molecular forms of TGase have been identified to date and have been found to exhibit differences in specificity. Among them, TGase 1, 3 and 4 were shown to be activated by proteolytic processing into forms with high specific activities respectively. One of the proteolytic enzymes was shown to be thrombin (Chung et al., 1998). The irreversible nature of fibrosis could have been contributed by the formation of covalent intermolecular crosslinks between different proteins by $\mathrm{Ca}^{2 *}$-dependent TGase (Richards et al., 1991). 
To date, the nature of radiation-induced early events that lead to the pathogenesis of the late lung injury remains obscure. In order to explore possible contribution of aberrant protein aggregation and crosslinking in eliciting pathogenesis of radiation-induced lung injury during $\mathrm{TBI}$ and $\mathrm{BMT}$ treatment, carbon monoxide uptake $\left(\mathrm{V}_{\mathrm{co}}\right)$ was measured following $\mathrm{TBI}$ and BMT and the levels of thrombin, TGases and crosslinked protein were analyzed in bronchoalveolar larvage (BAL) fluid during the early stages of $T B I$ and BMT.

\section{Materials and Methods}

\begin{abstract}
Animals and animal care
Female $\mathrm{C} 3 \mathrm{HeB} / \mathrm{FeJ}$ mice at 6-8 wks of age were obtained from Jackson Laboratory. They received neomycin-terramycin (Pfizer Co.), $0.3 \mathrm{~g} / \mathrm{L}$ tetracycline $\mathrm{HCl}$ and $0.2 \mathrm{~g} / \mathrm{L}$ neomycin sulfate triweekly in their drinking water. Both irradiated and unirradiated control animals were maintained on antibiotics throughout the experiment. In addition, mice receiving TBI and their un irradiated controls were housed in sterilized cages with filter bonnets, fed with autoclaved Purina Lab Chow (Samyang Co. Wonju, Korea), and given sterilized water for a period of 8 wks. The use of antibiotics and sterile conditions has been shown to improve survival and prevent respiratory infection following TBI. Animals were maintained in a temperaturecontrolled environment at $22^{\circ} \mathrm{C}$ on a $12 \mathrm{~h}$ light/dark cycle.
\end{abstract}

\section{Irradiation and dosimetry}

TBls were carried out using a ${ }^{\circ 0} \mathrm{Co}$ source. Mice were caged in lucite chambers $3 \mathrm{~cm}$ deep, $3 \mathrm{~cm}$ wide, and $6 \mathrm{~cm}$ long with a $0.5 \mathrm{~cm}$ thick lucite cover containing holes for ventilation. Eighty four such chambers were contained within a single irradiation jig. The chambers were sterilized prior to irradiation by immersion in $70 \%$ ethanol. Mice remained unanesthetized during irradiation and breathed room air. Dose rate to the mouse midline was measured in a polystyrene phantom at a depth of $1.2 \mathrm{~cm}$ using a calibrated ionization chamber. Maximum buildup of dose was achieved at the surface of the mouse jig. Uniformity of dose across the field was established by placing a piece of radiographic verification film between two $1 \mathrm{~cm}$ thick polystyrene sheets at the position of the mouse midline. Polystyrene sheets were placed around the mouse jig and rice bags were placed in chambers not containing mice to insure uniformity of dose due to scattered radiation. The animals received $\mathrm{TBl} ; 12 \mathrm{~Gy}$, $14 \mathrm{~Gy}, 16 \mathrm{~Gy}$ and $18 \mathrm{~Gy}$, at dose rate of $2.5 \mathrm{cGy} / \mathrm{min}$.

\section{BMT}

Animals receiving $\mathrm{TBI}$ also received a syngeneic bone marrow transplantation at 16-24 $\mathrm{h}$ following irradiation. Bone marrow was collected and prepared for transplantation by the method of Vallera et al. (1981). Approximately $2 \times 10^{6}$ nucleated bone marrow cells were inoculated intravenously into the tail vein of each recipient mouse.

\section{Steady-state $V_{\text {co }}$}

$V_{\text {co }}$ was determined according to the technique of DePledge et al. (1981). The concentration of rebreathed carbon monoxide $(\mathrm{CO})$ and helium $(\mathrm{He})$ were determined by $\mathrm{CO}$ and $\mathrm{He}$ analyzers (Hewlett-Packard $\mathrm{He}$ analyzer No. 47313A, CO analyzer No. 47312A, Willmington, Delaware). Output from the gas analyzers was read on a digital display or from a strip chart recorder. The standard gas mixture (SGM) used contained $10 \% \mathrm{He}, 0.3 \% \mathrm{CO}, 21 \% \mathrm{O}_{2}$ and balanced $\mathrm{N}_{2}$ (Matheson Gas Products, Joliet, IL).

Mice were placed into a $100 \mathrm{ml}$ syringe, and the plunger was inserted to confine the mouse in a minimum volume without compression. Approximately 80 $\mathrm{ml}$ of SGM was drawn via a gas collection bag into the $100 \mathrm{ml}$ syringe. The mice were allowed to rebreathe the gas for $90 \mathrm{~s}$, during which time the gas collection bag was flushed with air and evacuated. At the end of the rebreathing period, gas was expelled in to the evacuated collection bag and then automatically drawn into the analyzers. The percentage concentration of $\mathrm{CO}$ at the beginning and conclusion of the rebreathing period $\left(\mathrm{V}_{\mathrm{co}}\right)$ was calculated according to DePledge et al. (1981). Before each experiment the gas analyzers were calibrated with $80 \mathrm{ml}$ samples of SGM or $80 \mathrm{ml}$ samples of gas containing various proportions of SGM and air. This procedure was performed to determine factors $\left(\mathrm{CF}_{\mathrm{He}}\right.$ and $\mathrm{CF}_{\mathrm{co}}$ ) used to correct for sample size and flow dependence. In order to minimize the possible effects of diurnal rhythm, determinations of $V_{c o}$ were made during the early afternoon.

\section{BAL}

After trachea cannulation with plastic catheters attached to a $1 \mathrm{ml}$ syringe, the lungs were washed with sterile saline in five $0.6 \mathrm{ml}$ portions by gentle massage, and BAL fluid was collected to a total volume of $3 \mathrm{ml}$. The BAL fluid was centrifuged at $1,200 \mathrm{rpm}$ for $10 \mathrm{~min}$ at $4^{\circ} \mathrm{C}$ to precipitate the cells. The supernatant was stored at $-80^{\circ} \mathrm{C}$ before assay for thrombin and TGase activities, and identification of crosslinked protein. 
Determination of protease activity of thrombin in BAL fluid

The protease activity of thrombin was assayed fluoremetrically (16). Briefly, $80 \mu$ of $0.1 \mathrm{M}$ Tris- $\mathrm{HCl}$ buffer $(\mathrm{pH} 8.0), 100 \mu \mathrm{l}$ of $100 \mu \mathrm{M}$ Boc-Vat-Pro-Arg-MCA diluted with the buffer, and $20 \mu \mathrm{BAL}$ fluid were added to the wells of 96 well plates ( 8 White Maxisorp, Nunc, Denmark). The standard buffer contained various amounts of 7-amino-4-methylcoumarin. The plates were incubated at $37^{\circ} \mathrm{C}$ for $1 \mathrm{~h}$. Fluorescence intensity was measured by an MTP-32 (Hitachi, Tokyo, Japan) with an excitation wavelength of $365 \mathrm{~nm}$ and an emission wavelength of $450 \mathrm{~nm}$. Thrombin activity was expressed in nanomoles of substrate cleaved per $h$.

\section{TGase and XIII activity assay}

The thrombin activated FXIII- and TGase-activities were measured by an incorporation of $\left[1,4^{14} \mathrm{C}\right]$ putrescine $(100 \mu \mathrm{Ci} / \mathrm{mole})$ into the succinylated Hammersten casein assay as described (8). The assay solution contained $0.1 \mathrm{M}$ Tris-acetate buffer $\mathrm{pH} 8.0,1 \mathrm{mM}$ EDTA, $10 \mathrm{mM} \mathrm{CaCl}, 5 \mathrm{mM}$ DTT, $0.5 \%$ Lubrol (Sigma) and 1\% succinylated Hammersten casein. The reaction was started with an addition of $50 \mu$ of $0.5 \mathrm{Ci}$ radioactive putrescine into the $0.45 \mathrm{ml}$ of assay mixture containing $50 \mu \mathrm{l}$ of BAL fluid, and 1 $\mathrm{U}$ of thrombin at $37^{\circ} \mathrm{C}$ and stopped by addition of 4 $\mathrm{ml} 10 \%$ cold TCA solution. The casein precipitate was filtered on the glass filter (Whatmann GF/A) and the radioactivity was measured.

Distributions of TGase 1 and TGase 2 were examined by immunohistochemistry. For immunohistochemistry, 5 - $\mu \mathrm{m}$ sections were cut from wax-embedded tissue and immunostaining was detected by Tyramide Signal Amplification-Indirect Immunohistochemistry kit (NEN, Boston, MA). Sections were rehydrated and endogenous peroxidase activity was quenched with $3 \%$ (v/v) hydrogen peroxide in methanol. Sections were then blocked with appropriate blocking solution (NEN) and incubated with the respective primary antibodies in a humid chamber overnight at $4^{\circ} \mathrm{C}$. After washing in Tris-buffered saline (TBS) containing $0.05 \%$ tween 20 (T-TBS), a biotinylated secondary antibody (Sigma) diluted in the blocking solution was applied for $1 \mathrm{~h}$ at room temperature. After washing in T-TBS, the sections were incubated with a streptavidin-peroxidase conjugate (NEN) for $30 \mathrm{~min}$ at room temperature. Signal amplification was performed by incubating in biotinyl tyramide working solution (NEN) and then sections were reincubated with a streptavidin-peroxidase conjugate. After washing with T-TBS, tissue bound peroxidase was detected using $0.2 \% 3,3^{\prime}$-diaminobenzidine in TBS. Sections were counterstained with hematoxylin. Primary antibodies (polyclonal) were goat anti-human recombinant TGase 1 , and goat anti- guinea pig TGase 2 which were kindly donated by Dr. Chung SI (Aju University, Korea).

\section{Isolation and identification of crosslinked proteins}

BAL fluid was boiled for 4 days at $110^{\circ} \mathrm{C}$ in solution containing $2 \%$ SDS, $10 \mathrm{M}$ urea, $40 \mathrm{mM}$ DTT. The boiled suspension was dialyzed against distilled water, centrifuged for $30 \mathrm{~min}$ at $15,000 \mathrm{rpm}, 4^{\circ} \mathrm{C}$. The pellet was then washed twice with distilled water and lyophilized. The insoluble precipitate resuspended in PBS was electrophoresed on $4-12 \%$ gradient SDSpolyacrylamide gel. Proteins were stained with Coomassie brilliant blue.

\section{Western blot analysis}

After the protein concentration of BAL fluid was determined, equal amounts of the samples $(30-50 \mu \mathrm{g})$ were separated on a $12 \%$ SDS-polyacrylamide gel. After electrophoresis, the gel was transferred to a nitrocellulose membrane in an Xcell blot module (Novex, San Diego, CA). The membrane was incubated overnight with goat polyclonal anti-human rTGase 1, anti-guinea pig TGase 2 and anti-rabbit XIII, and monoclonal anti-isopeptide antisera. After washing the blots to remove unbound antibodies, the proteins of interest were visualized with the ECL system (Amersham, Buckinghamshire, UK).

\section{Statistics}

There were 15 mice per group for experiments invor ving $T B I$ and seperate additions of 6 mice 1 and 2 wk after $12 \mathrm{~Gy}$ TBI were used to examine thrombin-, TGase- and XII-activities and crosslinked proteins in BAL fluid. Mean and standard error of the means were calculated for each group. Intergroup comparisons were made with Student's $t$ test. $P$ values of 0.05 or less were considered significant.

\section{Results}

\section{Carbon monoxide uptake ( $\left.\mathrm{V}_{\mathrm{co}}\right)$}

The effect of graded single doses of TBI followed by BMT on $V_{\infty}$ is shown in Figure 1. TBI and BMT caused a decrease in $V_{c o}$ that began during the first 1 month after treatment, and the $V_{\infty}$ was significantly reduced below control levels.

\section{Thrombin activity}

The thrombin activity in BAL fluid of control (unirradiated) mice was $7.08 \mathrm{U}$, whereas the activities of TBI-BMT mice were significantly higher than that of 


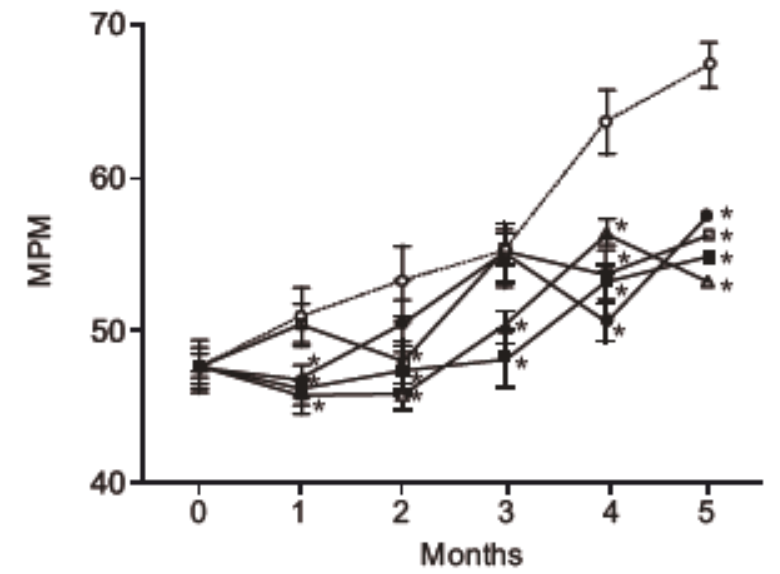

Figure 1. $V_{\infty}$ (MPM=microliter per $\left.\mathrm{min}\right)$ as a function of months after a range of single doses of TBI and BMT. - - - control;

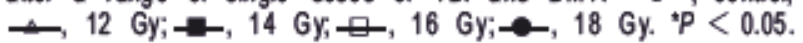

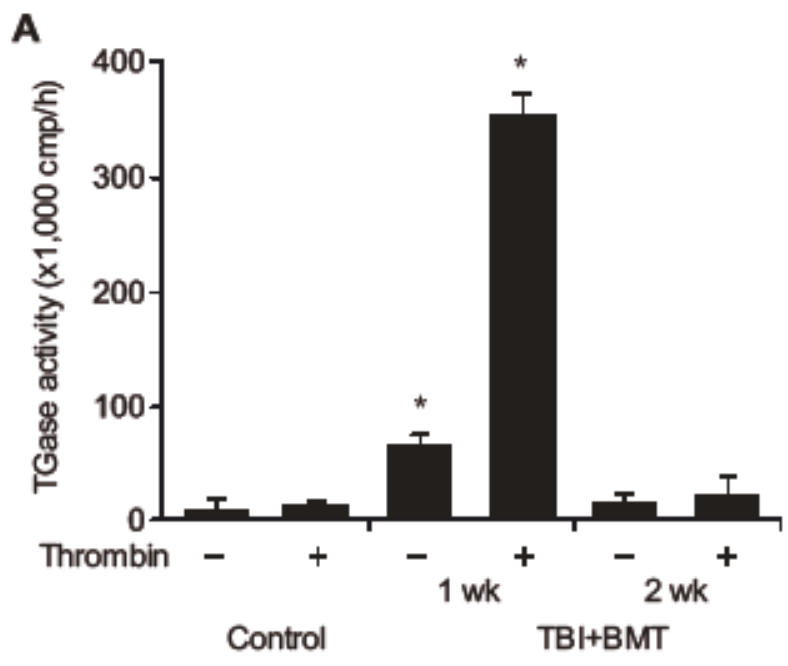

B

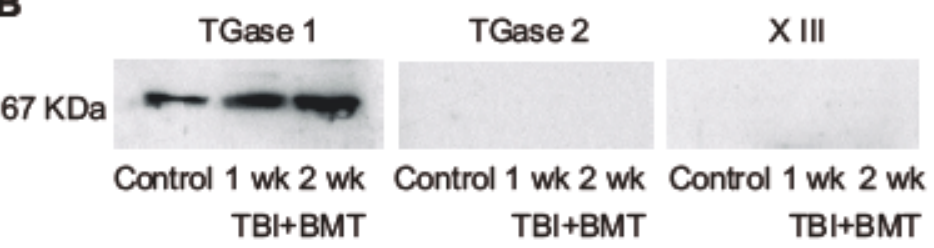

Figure 3. (A) TGase activity in BAL fuid fom unirradiated and irradiated mice. BAL was performed at 1 and 2 wks after irradiation. TGase activity was measured by $\left[{ }^{14} \mathrm{C}\right.$-putrescine incorporated into dissuccinylated casein mehod, as described in Malerials and Methods. ${ }^{*} P<0.05$. (B) Expression pattems of TGases in BAL fuid from unirradiated and irradiated mice. Equal amounts $(30 \mu \mathrm{g})$ of $\mathrm{bbl}$ proleins were analyzed by Western blot. (C) Immunohistochemistry of TGase 1 (a) and 2 (b). A portion of lung from unirradiated mice(upper panels) and mice 1 wk after TBI and BMT (lower panels), showing strong immunoreactivity, immunoperoxidase stain, scale bar, $100 \mu \mathrm{m}$.
Figure 2. Thrombin activity in BAL fuid from irradiated mice. BAL was performed at 1 and 2 wks after irradiafon. Thrombin activity was assayed fuorometrically with Boc-Val-Pro-Arg-MCA as a substrale, as described in Materials and Methods. Thrombin activity in BAL. fuid was expressed as nanomoles of substrale per $h$. Values represent means $\pm S E M$, with $n=3$. ${ }^{*} P<0.05$.

C

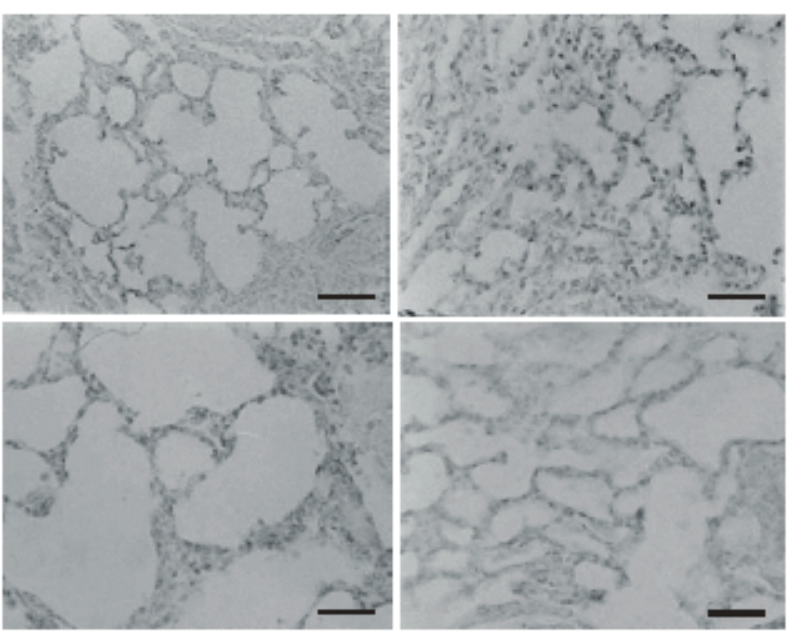


control mice $(P<0.05), 55.2 \mathrm{U}$ and $22.7 \mathrm{U}$ at $1 \mathrm{wk}$ and 2 wks after TBI of 12 Gy and BMT, respectively (Figure 2).

\section{TGase and XIII activities}

As shown in Figure 3, TGase activities were detected only in BAL fluid from mice 1 wk after TBI of $12 \mathrm{~Gy}$ and BMT. The activities were never detected in the BAL fluid from unirradiated control mice and from mice 2 wk after TBI and BMT. The TGase activity was $63,000 \mathrm{cpm} / \mathrm{h}$ in the absence of thrombin, whereas the activity was 5.5 fold enhanced to $352,800 \mathrm{cpm} / \mathrm{h}$ in the presence of thrombin (A). Western blot analysis (B) showed expression of the $67 \mathrm{KDa}$ TGase 1 protein in BAL fluid from control mice, and the mice 1 wk and 2 wks after TBI and BMT. TGase 2- and XIIproteins were never expressed. Immunohistochemistry (C) revealed the immunoreactivities of both TGase 1 and TGase 2 in lung parenchymal cells from unirradiated (control) and irradiated mice. Thus, the increased TGase activity in the presence of thrombin from BAL fluid from the mice 1 wk after TBI and BMT appears to be TGase 1 .

\section{Crosslinked protein}

To investigate the nature of the insoluble protein in BAL fluid, it was extensively boiled in urea, and SDS-

\section{A}

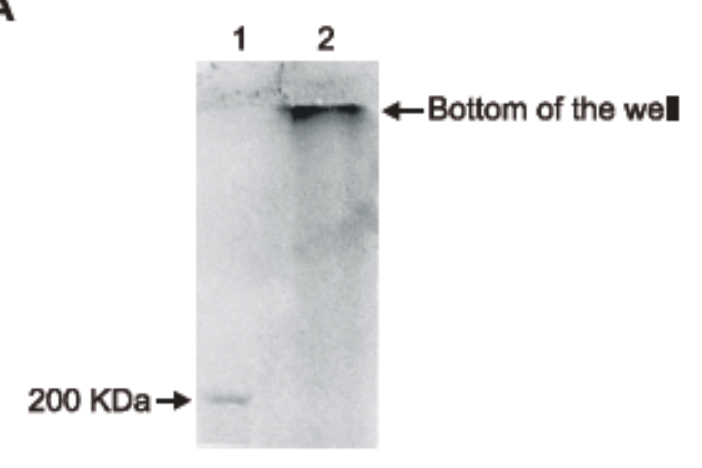

B

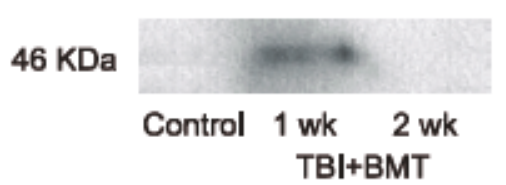

Figure 4. (A) SDS-PAGE of isopeptide linked protein. BAL fuid from mice 1 wk after TBI and BMT was bolled for 4 days in Tris buffer, pH 8.5 containing $10 \mathrm{M}$ urea, $2 \%$ SDS, $40 \mathrm{mM}$ DTT. solated isopeptde linked prolein was electrophoresed on 4-12\% gradient SDSPAGE, and stained with Coomassie blue R. lane 1: molecular weight marker; lane 2: isopepide linked protein. (B) Expression of isopeptidebound crosslinked protein in BAL fluid fom mice 1 wk after TBI and BMT by Westem blot.
PAGE was performed. The insoluble protein did not migrate on $4-12 \%$ gradient SDS-PAGE, indicating that the protein is crosslinked (Figure 4A), and the isopeptide of the protein was confirmed by Western blot analysis (Figure 4B).

\section{Discussion}

Although BMT is now a standard treatment for leukemias and other hematological malignancies, the preparatory $\mathrm{TBI}$ undertaken prior to BMT predisposes the patient to lung complications with a significant fatality rate. In the current study, we demonstrated that TBIinduced lung damage involves a decrease in $V_{\infty}$, enhanced activities of thrombin and TGase 1 and the elevation of crosslinked protein in BAL fluid. $V_{c o}$ is known as a very sensitive indicator of detecting lung radiation injury (Travis et al., 1979; DePledge et al., 1981). Our results do show significant decrease of CO levels following irradiation and support the previous work of DePledge et al. (1981). Reduced $V_{c o}$ could be due to a decrease in the capillary-alveolar bed, uneven distribution of ventilation or perfusion, a change in the surface active properties of alveoli, or a change in the composition of alveolar septae (Roughton and Forster, 1957).

BAL (Steinberg et al., 1993) is a melieu containing eluants of all the soluble components out of lung cells and allows for detecting any component changes that may be associated with the pathogenesis of radiationinduced lung damage. Based on such analysis, numerous lead candidates for lung radiation injury have been reported-TGF- $\beta$ (Anscher et al., 1995), IL-4 (Büttner et al., 1997), IL-6 (Chen et al., 2001), and thrombin (Huang et al., 2001).

Thrombin activity greatly elevated in BAL fluid from thorax-irradiated rats has been reported to possess the proliferative activity of fibroblasts (Huang et al., 2001). TGases are involved in the remodeling of granulation tissue through cross-linking (Haroon et al., 1999). Most of the TGase1 in epithelial cells has been known to exist as $a \simeq 100 \mathrm{kDa}$ membrane-bound protein with low specific activity, but during terminal differentiation, some may be activated by proteolytic processing into a $67 / 33 / 10 \mathrm{kDa}$ form with high specific activity, and some intact low specific activity or higher specific activity processed forms are released into the cytosol (Steinert et al., 1996). The $\simeq 80 \mathrm{kDa}$ TGase 2 enzyme is typically located in the cytosol and welt known to ubiquitously express tissue TGase (Folk and Finlayson, 1977). Cocuzzi and Chung (1986) reported the high expression of the TGase 1 in normal lung tissues. In the present study, thrombin- and TGase 1 activities and crosslinked proteins were identified in the BAL fluid of mice after TBI and BMT, and the 
expression of TGase 1 and 2 could be seen in lungs from both unirradiated and irradiated mice, indicating that TGase 1 of BAL fluid from the mice 1 wk after $T B I$ and BMT appears to be mobilized from the lung parenchymal cells.

In this study, the $67 \mathrm{KDa}$ TGase 1 protein in BAL fluid from unirradiated mice and from mice $1 \mathrm{wk}$ and 2 wks after TBI and BMT was confirmed by Western blot analysis. However, no enzyme activities were detected in the BAL fluid from unirradiated mice and from the mice 2 wks after TBI and BMT and remains to be clarified. It has been well recognized that the crosslinked protein formed by TGases in the early stage of inflammation confers mechanical stability which is known to be provisional matrix (Lorand and Conrad, 1984). Thus, although no TGase 1 activity in bronchoalveolar fluid from the mice 2 wks after TBI and BMT was observed, the crosslinked proteins formed by TGase 1 in the bronchoalveolar fluid from the mice 1 wk after TBI and BMT, appear to initiate fibrosis. In pulmonary damage, it is speculated that the activation of TGase 1 by thrombin, the $\mathrm{Ca}^{2+}$-dependent enzyme responsible for catalyzing the crosslinks, together with enhanced levels of substrate proteins such as fibrin, fibrinogen, and fibronectin, could lead to the formation of stable excessive matrix crosslinked proteins.

This study provides evidence that the bronchoalveolar proteins crosslink by the thrombin-activatable TGase 1 in the early stages of radiation-induced lung damage followed by reduced lung function. This study seems to be the first to examine the expression of TGase 1 and the formation of $N^{2}-(\gamma g$ lutamyl) lysine crosslinks in BAL fluid of the injured lung after TBI and BMT.

\section{Acknowledgement}

This work was partly supported by Catholic Medical Center Grant 2003.

\section{References}

Anscher MS, Kong FM, Andrews K, Clough R, Marks LB, Bentel G, Jirtle RL. Plasma transforming growth factor 1 as a predictor of radiation pneumonitis. Int J Radiation Oncol Biol Phys 1998;41:1029-35

Büttner C, Skupin A, Reimann T, Rieber EP, Unteregger G, Geyer $\mathrm{P}$, Frank KH. Local production of interleukin-4 during radiation-induced pneumonitis and pulmonary fibrosis in rats: macrophages as a prominent source of interleukin-4. Am J Respir Cell Mol Biol 1997;17:315-25

Chen $Y$, Rubin $P$, Williams $J$, Hernady $E$, Smudzin $T$, Okunieff $P$. Circulating IL-6 as a predictor of radiation pneumonitis. Int J Radiation Oncology Biol Phys 2001;49:641-8

Chung SI, Chang SK, Cocuzzi ET, Folk JE, Kim HC, Lee
SY, Martinet N, Nigra T, Sun HS. Modulation of cellular transglutaminase: Protease-induced activation. In Advances in post-translational modifications of proteins and aging. V. Zappia, P. Galletti, R. Porta, F. Wold, editor. Plenum Pulishing, New York, 1-13, 1988

Cocuzzi ET, Chung SI. Cellular transglutaminase, lung matrixassociated transglutaminase: characterization and activation with sulfhydryls. J Biol Chem $1986 ; 261: 8122-7$

Depledge $\mathrm{MH}$, Collis $\mathrm{CH}$, Barrett A. A method for measuring carbon monoxide uptake in mice. Int J Radial Oncol Biol Phys 1981;7:485-9

Folk JE, Finlayson JS. The $\mathrm{N}^{\mathrm{E}}$ ( $\gamma$-glutamyl) lysine crosslink and the catalytic role of trnsglutaminases. Adv Prot Chem $1977 ; 31: 1-133$

Haroon ZA, Hettasch JM, Lai TS, Dewhist MW, Greenberg CS. Tissue transglutaminase is expressed, active, and $\mathrm{di}$ rectly involved in rat dermal wound healing and angiogenesis. FASEB J 1999;13;1787-95

Huang L,Ogushi $F$, Tani $K$, Ogawa $H$, Kawano $T$, Endo $T$, Izumi $\mathrm{K}$, Sono $\mathrm{N}$, Ueno J, Nishitani $\mathrm{H}$, Sone $\mathrm{S}$. Thrombin promotes fibroblast proliferation during the early stages of experimental radiation pneumonitis. Radiation Research 2001; $156: 45-52$

Kersey JH, Ramsay NKC, Kim TH, McGlave P, Krivit W, Levitt S, Filipovich A, Woods W, O'Leary M, Coccia P, Nesbit ME. Allogeneic bone marrow transplantation in acute nonlymphocytic leukemia: a pilot study. Blood 1982;60:400-3

Kim SY, Chung SI, Steinert PM. Highly active soluble processed forms of the transglutaminase 1 enzyme in the epidermal keratinocytes. J Biol Chem 1995;270:18026-35

Lorand L, Conrad SM. Transglutaminases. Mol Cell Biochem $1984 ; 58: 9-35$

McGlave PB, Arthur DC, Kim TH, Ramsay, NKC, Hurd DD, Kersey J. Successful allogeneric bone-marrow transplantation for patients in the accelerated phase of chronic granulocytic leukaemia. Lancet 1982;18:625-7

Molls $M$, Budach V, Bamberg M. Total body irradiation: the lung as critical organ. Strahlentherapie und Onkologie 1986; $162: 226-32$

O'Leary M, Ramsay NKC, Nesbit ME, Hurd D, Woods WG, Krivit W, Kim TH, McGlave P, Kersey J. Bone marrow transplantation for non-Hodgkin's lymphoma in children and young adults. A polot study. Am J Med 1983;74:497-501

Penney DP, Rubin P. Specific early fine structural changes in lung irradiation. Int J Rad Oncol Biol Phys 1977;2:1123-32

Rappaport DS, Niewoehner DE, Kim TH, Song CW, Levilt $\mathrm{SH}$. Uptake of carbon monoxide by $\mathrm{C} 3 \mathrm{H}$ mice following $\mathrm{X}$ irradiation of lung only or total-body irradiation with ${ }^{80} \mathrm{Co}$. Radial Res 1983;93:254-61

Richards RJ, Maseck LC, Brown RF. Biochemical and cellular mechanisms of pulmonary fibrosis. Toxicol Pathol $1991 ; 19: 526-39$

Roughton FJW, Forster RE. Relative importance of diffusion and chemical reaction rates in determining rate of exchange of gases in the human lung, with special reference to true diffusing capacity of pulmonary membrane and volume of 
blood in the lung capillaries. J Appl Physiol 1957;11:290-302

Steinberg F, Quabeck K, Rehn B, Kraus R, Mohnke M Costabel U, Kreuzfelder E, Molls M, Bruch J, Schaefer UW, Streffer C. Lung effects after total body irradiation of mice and bone marrow transplant: comparison of experimental and preliminary clinical data. Recent Results in Cancer Research 1993;130:133-43

Steinert PM, Chung SI, Kim SY. Inactive zymogen and highly active proteolytically processed membrane-bound forms of the transglutaminase 1 enzyme in human epidermal keratinocytes. Biochem Biophys Res Commun 1996;221:101-6
Travis EL, Vojnovic B, Davies EE, Hirst DG. A plethysmographic method for measuring function in locally irradiated mouse lung. $\mathrm{Br} \mathrm{J}$ Radial 1979;52:67-74

Vallera DA, Soderling CCB, Carlson GJ, Kersey JH. Bone marrow transplantation across major histocompatibility barriers in mice. Effect of elimination of $T$ cells from donor grafts by treatment with monoclonal Thy-1.2 plus complement or antibody alone. Transplantation 1981;31:218-22

Vriesendorp HM, Chu H, Ochran TG, Besa PC, Champlin RE. Radiobiology of total body radiation. Bone Marrow Transplantation $1994 ; 4: S 4-8$ 